\title{
TRANSACTIONS
}

OF THE

\section{ROYAL SOCIETY OF EDFNBURGH}

\author{
VOLUME LXVII, 1967-68
}

3. Trilobites from the Upper Stinchar Limestone (Ordovician) of the Girvan District, Ayrshire. By Ronald Pearson TripP. (With Six Plates.) Price: $25 \mathrm{~s}$.

(Issued June 9, 1967.)

4. Some Specimens of Protoclepsydropsis and Clepsydropsis from the Calciferous Sandstone Series of Berwickshire. By Albert G. Long, M.Sc., F.R.E.S., Hancock Museum, Newcastle upon Tyne. (With Four Plates, Two Text-figures and One Table.) Price: 11s. $\quad$ (Issued June 2, 1967.)

5. The Explosion-breccia Pipes near Kentallen, Scotland, and their geological setting. By D. R. BowES, M.Sc., PhD., D.I.C., F.G.S., Department of Geology, University of Glasgow and A. E. WRIGHT, Ph.D., F.G.S., Department of Geology, University of Birmingham. Communicated by Professor T. Neville George, F.R.S. (With Two Plates, One Map and Seventeen Text-figures.) Price: $20 \mathrm{~s}$.

(Issued August 9, 1967.)

6. Vegetational Change, Shoreline Displacement and the Human Factor in the Late Quaternary History of South-West Scotland. By HarveY Nichols, Ph.D., Department of Meteorology, University of Wisconsin, Madison, Wisconsin, U.S.A. Communicated by Dr H. R. FletcheR and Dr G. H. Mitchell, F.R.S. (With Twelve Text-figures.) Price: $25 s$.

(Issued August 23, 1967.)

7. The Littoral Copepoda (Crustacea) of Inhaca Island, Mozambique. By J. B. J. Wells, Natural History Department, Marischal College, University of Aberdeen. Communicated by Professor V. C. Wynne-EDWARDS. (With Seventy-eight Text-figures and Eight Tables.) Price: £5

(Issued September 11, 1967.)

8. Some specimens of Mazocarpon, Achlamydocarpon and Cystosporites from the Lower Carboniferous Rocks of Berwickshire. By Albert G. LoNG, M.Sc., F.R.E.S., Hancock Museum, Newcastle upon Tyne. (With Four Plates and Two Text-figures.) Price: $14 s$.

(Issued February 28, 1968.)

9. The Placoderm Fish Coccosteus cuspidatus Miller ex Agassiz from the Middle Old Red Sandstone of Scotland. Part I. Descriptive Morphology. By Roger S. Miles, Ph.D. and T. Stanley Westoli, D.Sc., F.R.S., Department of Geology, University of Newcastle upon Tyne. (With Twelve Plates and Fifty-one Text-figures.) Price: $52 s .6 d$.

(Issued May 22, 1968.)

10. Kochiproductus coronus sp. nov. from the Scottish Visean and a Possible Mechanical Advantage of its Flange Structure. By K. A. G. SHiells, Department of Geology, University of Glasgow. (With One Plate and Twenty Text-figures.) Price: 17s. (Issued June 14, 1968.)

Title page, Contents and Index

VOLUME 68, 1968-

1. Further Observations on the Scottish Carboniferous Eurypterids. By ChARLES D. WATERSTON, B.Sc, Ph.D., F.G.S., Department of Geology, Royal Scottish Museum. (With Three Plates, One Text-figure and One Table.) Price: 15s. (Issued June 19, 1968.)

2. On the Heteromyarian Condition in the Bivalvia with Special Reference to Dreissena polymorpha and Certain Mytilacea. By C. M. Yonge and J. I. CAMpbel L, Department of Zoology, University of Glasgow. (With Seventeen Text-figures.) Price: 14s. (Issued June 26, 1968.)

Fellows of the Society purchasing publications for their own use will be allowed a special discount of 3.31 per cent on the current prices (see Law XVI). 